\title{
Distribution Intensity, Advertising, Monetary Promotion, and Customer-Based Brand Equity: An Applied Study in Egypt
}

\author{
Ahmed Y. Ebeid ${ }^{1 \& 2}$ \\ ${ }^{1}$ Business Administration Department, Faculty of Commerce, Mansoura University, Egypt \\ ${ }^{2}$ Business Administration Department, Faculty of Business Administration, Delta University for Science and \\ Technology, Egypt \\ Correspondence: Ahmed Y. Ebeid, Associate Professor, Business Administration Department, Faculty of \\ Commerce, Mansoura University \& Head of Business Administration Department, Faculty of Business \\ Administration, Delta University for Science and Technology, Egypt. E-mail: a_yehia75@yahoo.com
}

Received: May 1, $2014 \quad$ Accepted: June 2, $2014 \quad$ Online Published: July 28, 2014

doi:10.5539/ijms.v6n4p113 URL: http://dx.doi.org/10.5539/ijms.v6n4p113

\begin{abstract}
Brand equity is so essential issue to be considered by manufacturers and retailers as well, that is to manage the brand rationally. The aim of the current research is to support managers in terms of determining the expected influence of marketing activities on the brand equity, which implies for the relative fund each activity deserves. The study investigated the potential effects of brand equity drivers (i.e., distribution intensity, advertising, monetary promotion) on the dimensions of customer-based brand equity. In addition, the research investigates the inter-relationships among the dimensions of brand equity. The study was built on data derived from 497 respondents. The results indicate that the proposed model reflects perfect fit to the data. The most of the hypothesized influences were significant and took the expected directions. The results would lead to suggest that brand awareness is the starting point to constitute the customer-based brand equity. Discussion and implications are provided.
\end{abstract}

Keywords: brand equity, distribution intensity, monetary promotion

\section{Introduction}

Brand is "a name, term, sign, symbol, or design, or a combination of these that identifies the maker or seller of a product or service" (Kotler \& Armstrong, 2008, p. 225). These individual components named "brand identities" (Keller, 1993). Berry (2000, p. 128) stated that "in packaged goods, the product is the primary brand, however, with services the company is the primary brand." Brand is considered an important firms' intangible asset (Keller \& Lehmann, 2006) that should carefully be managed in order to reach their maximum value (Simon \& Sullivan, 1993). Due to the increasing competition, Bambauer-Sachse and Mangold (2011) referred that, studying brands would take more concern. All value chain constituents benefit from the brand (Baldauf, Cravens, Diamantopoulos \& Zeugner-Roth, 2009). In case, the consumers are uncertain about the attributes of the product, a firm would rely on the brand as a tool in terms of emphasizing the product credibility, thus decreasing the information costs, and consumer 's risk perception (Erdem \& Swait, 1998), and enhances the value shopper gets from the product (Kim \& Hyun, 2011). In another word, brand would facilitate the customer choice (Keller \& Lehmann, 2006). The ability to create and manage brand is a skill that could be used to differentiate between marketers (Kotler \& Armstrong, 2008). At this point, brand equity would be seen as the brand achievement (Buil, Chernatony \& Martínez, 2013). Specifically, brand equity could be defined as "a set of brand assets and liabilities linked to a brand, its name and symbol that add to or subtract from the value provided by a product or service to a firm and/or to the firm's customers" (Erdem, Swait, Broniarczyk, Chakravarti, Kapferer, Keane, Roberts, Steenkamp, \& Zettelmeyer, 1999, p. 302). Brand equity is value granted by the brand to the product (Chattopadhyay, Dutta, \& Sivani, 2010; Yoo \& Donthu, 2001; Yoo, Naveen, \& Sungho, 2000; Park \& Srinivasan, 1994; Keller, 1993; Simon \& Sullivan, 1993, Srinivasan, Park, \& Chang, 2005), thus it is an interesting matter in both, industrial and consumer marketing (Kim \& Hyun, 2011). Brand equity considered a pivotal issue in the marketing domain for practitioner and academics as well (Buil et al., 2013; Baldauf et al., 2009), which could be noticed since the late of 1980s (Srinivasan et al., 2005). The firm`s success (Yoo et al., 2000) and total value (Simon \& Sullivan, 1993) may depend on how far the firm succeeds in managing its brand equity. Matching with 
win-win philosophy, Yoo, et al. (2000) stated that brand equity would generate value to different stakeholders (i.e., firm; customers; employees; shareholders; and management). Brand equity considered a measurement for evaluating the effect of long-term marketing activities (Yoo \& Donthu, 2001; Simon \& Sullivan, 1993; Aaker, 1996), and it would be seen as a proxy of performance (Kim \& Hyun, 2011). It is a complicated matter to allocate the marketing budget (Soberman, 2009), although, firms seek to fund each element of marketing mix rationally (Keller, 1993). This may lead to choose between two alternatives; to invest in the current brands, or incurring escalating costs for developing new brands (Simon \& Sullivan, 1993). As elements of brand equity affect consumer's perceptions and brand buying behavior as well (Buil et al., 2013), determining such elements and their roles in creating brand equity would be used as a basis for allocating the marketing budget. From the other hand, financial motivation (e.g., accounting purposes) recalls the need for studying brand equity (Keller, 1993). In addition, to enhance the manufacturers bargaining power in the front of retailers, they need to strengthening their brands (Park \& Srinivasan, 1994). The first study investigated the relationships between marketing activities and brand equity was the study of Yoo, et al. (2000). It is important matter for managers to realize the various effect of marketing activity on the brand equity (Keller, 1993). In their study, Baldauf, et al. (2009) emphasized the necessity of examining the factors actually build brand equity. The research demonstrated the influential role of marketing mix elements in creating the brand equity (Van Riel, Sandra, \& Mortanges, 2005; Ailawadi, Lehmann \& Neslin, 2003; Yoo et al., 2000; Keller, 1993). The aim of the current research is to support managers in terms of determining the expected influence of marketing activities on the brand equity, which implies for the relative fund each activity deserves. Specifically, the current research would reach this aim by investigating the potential effects of distribution intensity, advertising, and monetary promotion (i.e., brand equity drivers) on the dimensions brand equity, that is, brand awareness, brand associations, brand loyalty, and perceived quality. In addition, the research investigates the inter-relationships among the dimensions of brand equity. Building on the Parameswaran and Yaprak's (1987, p. 45) finding "the same scales may have different reliabilities in different cultures, and that the same scales may exhibit different reliabilities when used by the same individual in evaluating products from different cultures." The current research may provide more (less) generalizability in terms the results of the previous work that has been done in the area of brand equity, by shedding more light on antecedents of brand equity (i.e., distribution intensity, advertising, and monetary promotion), among Egyptian consumers who hold a unique culture, and consuming different products from different culture.

\section{The Conceptual Framework}

\subsection{Brand Equity}

It appears once a customer has favorable, strong and unique associations toward a specific brand (Keller, 1993), or when the customer has a brand preference (Park \& Srinivasan, 1994) relative to a product with no brand-building effort (Srinivasan et al., 2005), or in comparison to a weaker brand name providing the same attributes (DelVecchio, Jarvis, Dineen, \& Klink, 2007). While many researchers (e.g., Kim, Jin-Sun, \& Kim, 2008; Park \& Srinivasan, 1994) referred to a degree of agreement, at a conceptual level, regarding what brand equity means, Yoo and Donthu (2001) argue that there is no agreement in terms of what brand equity is. Using consumer-based behavioral view, Yoo and Donthu (2001, p.1) defined brand equity as "consumers' different response between a focal brand and an unbranded product when both have the same level of marketing stimuli and product attributes."

\subsection{The Approaches to Conduct Brand Equity}

Brand equity has been addressed from different perspectives (Netemeyer et al., 1998; Keller, 1993), which would result in different brand equity measures. From the organizational-based equity (Kim et al., 2008), brand equity would be measured on the basis of the incremental cash flows that resulted from investing in a brand (Ailawadi et al., 2003; Park \& Srinivasan, 1994; Simon \& Sullivan, 1993). This financial perspective is unbiased and precise brand's value estimation, and could be used for accounting (Kim et al., 2008), merger and acquisition purposes (Yoo \& Donthu, 2001). Although, the value of this approach is limited; it is not valuable enough to provide managers with insights to develop marketing strategies (Kim et al., 2008), as researchers who adopt this approach collect data without contacting consumers (Yoo \& Donthu, 2001). In addition, it does not enable managers to manage each brand appropriately, in case that the firm has different brands and operating in different markets, that is because this method is dependent on data aggregated to the firm (Park \& Srinivasan, 1994). On the other hand, there is another approach which emphasizes the value of a brand to consumers (Erdem \& Swait, 1998), that is, customer-based brand equity (Kim et al., 2008; Netemeyer et al., 2004), or it may be named customer-mind set "which focuses on assessing the customer based sources of brand equity" (Ailawadi et al., 2003, p.2). Customer-based brand equity is defined as "the differential effect of brand knowledge on 
consumer response to the marketing of the brand" (Keller, 1993, p. 2). Author noticed that Kotler's (2008) brand equity definition is similar to Keller's definition, but Kotler uses wording "positive differential effect" not just a "differential effect". It is an interesting matter to conducting brand equity, from the customer basis (Bambauer-Sachse \& Mangold, 2011). Customer-based brand equity, relative to financial approach, is more practical approach, focuses on customers ' mindset (e.g., awareness and perceived quality), as Kim, et al. (2008), or emphasizes customer perceptions, as Netemeyer, et al. (2004) referred. Customer-based brand equity conceptualization helps managers in developing marketing strategies (Kim et al., 2008), and providing significant resource to preserve brand equity (Bambauer-Sachse \& Mangold, 2011). Ailawadi, et al. (2003) concluded that each perspective that addresses brand equity has a set of advantages as well as disadvantages. In another word, there is no optimal measure that could be used to fulfill marketers' desire in terms of measuring brand equity (Ailawadi et al., 2003). Eventually, the customer-based brand equity is the approach the research adopts, since the researcher sees that addressing the consumer directly (i.e., customer-based brand equity) would generate more insights that marketers build on, in terms of planning the marketing activities.

\subsection{Dimensions of Customer-Based Brand Equity}

Brand equity is "a multidimensional concept" (Chattopadhyay et al., 2010, p. 174). Brand equity dimensions, based on customer perceptions, are brand awareness, brand associations, brand loyalty, and perceived quality) (e.g., Buil et al., 2013; Aaker, 1996).

\subsubsection{Brand Loyalty}

Aaker (1996) considers loyalty as an essential dimension of brand equity, and places it the first dimension to be conducted, in terms of studying brand equity. Brand loyalty would be seen as "a strong form of attachment refers to the resistance to change and the ability of a brand to survive in fluctuating environments" (Kim et al., 2008, p. 237). Loyal customers reflect more favorable response to a brand relative to non loyal ones (Chattopadhyay et al., 2010), and represent additional advantages (e.g., a barrier to entry) to the firm (Aaker, 1996).

\subsubsection{Perceived Quality}

Aaker (1996, p. 109) revealed that "perceived quality is one of the key dimensions of brand equity, and an association that is usually central to brand equity." Perceived quality relates to the consumer's subjective evaluation regarding a product's overall excellence or superiority (Chattopadhyay et al., 2010).

\subsubsection{Brand Awareness}

Keller (1993) relates brand awareness to likelihood and the ease that the brand name comes to the consumer's mind. Erdem et al. (1999) and Keller (1993) referred that brand awareness could be conducted in terms of brand recognition and brand recall. Brand recognition reflects the prior consumer's exposure to the brand (Keller, 1993) or hearing about it (Aaker, 1996), when the cue is the brand, while brand recall reflects the ability that the consumer has in terms of retrieving the brand (Aaker, 1996; Keller, 1993) when the cue is the category (Keller, 1993). As Huang and Sarigöllü (2012) did not divide brand awareness into brand recall and brand recognition, the current study does. Hoyer and Brown (1990) revealed that brand awareness would influence the consumer choice process, as it may simplify choice process if the brands quality differences exist, that is to economizing time and effort.

\subsubsection{Brand Association}

It considered one of the most important component of consumer-based brand equity (Romaniuk \& Nenycz-Thiel, 2013), and it refers to anything about brand that the customer's memory holds (Chattopadhyay et al., 2010). Keller (1993, p. 3) stated that "the favorability, strength, and uniqueness of brand associations are the dimensions distinguishing brand knowledge that play an important role in determining the differential response that makes up brand equity, especially in high involvement decision settings. When conducting brand awareness and brands associations, the author encountered with two approaches. The first approach combines them into a single dimension (e.g., Kim \& Hyun, 2011; Baldauf et al., 2009). The second approach addresses brand awareness and brand associations separately (e.g., Buil et al., 2013; Aaker, 1996), as the current research does. In summary, brand awareness and brand associations considered major elements that brand equity resulted from (Erdem et al., 1999). Building on literature, this study addresses brand loyalty, perceived quality, brand awareness, and brand associations as dimensions of brand equity.

\section{Research Hypotheses}

\subsection{Distribution Intensity and Dimensions of Brand Equity}

To define distribution intensity, Yoo et al. (2000, p. 199) revealed that "distribution is intensive when products 
are placed in a large number of stores to cover the market." Srinivasan et al. (2005) stated that brand awareness could be increased when the distribution increased. The product availability would enhance the consumer satisfaction (Yoo et al., 2000). Yoo et al. (2000) reported that distribution intensity would increase brand equity. Huang and Sarigöllü (2012) found that distribution intensity positively enhances brand awareness. The data of Yoo, et al.'s (2000) study supported the positive hypothesized relationship between distribution intensity and perceived quality, and between distribution intensity and brand loyalty, while the hypothesized relationship between distribution intensity and brand associations/awareness was not supported. Accordingly, author hypothesizes that:

Distribution intensity positively affects brand awareness, perceived quality, and brand loyalty.

\subsection{Advertising and Dimensions of Brand Equity}

Keller and Lehmann (2006) referred to the advertising effect on the brand that is by considering brand as a determinant of the advertising effectiveness. Advertising generates value (Cobb-Walgren, Ruble \& Donthu, 1995), as it increases the brand awareness (Buil et al., 2013; Srinivasan et al., 2005; Yoo et al., 2000; Buil et al., 2013; Cobb-Walgren et al., 1995), and participates in creating brand equity (Chattopadhyay et al., 2010). Although, Buil, et al. (2013) revealed that advertising does not necessarily support brand associations, Cobb-Walgren et al (1995) found a significant positive relationship between advertising and brand associations; that is true with cleansers, although for hotels, they stated that the associations were neutral or negative. Yoo, et al. (2000); Simon and Sullivan (1993) stated that advertising positively enhances brand associations. "The consumer believes that the more a brand advertises, the more likely it is to be a better buy. In consequence, the more advertisements of a brand the consumer encounters, the more likely he is to try the brand" (Nelson, 1974, p. 732). Simon and Sullivan (1993) stated that advertising would influence brand associations. Yoo et al. (2000) stated that advertising spend increases the consumers` perceived quality. Simon and Sullivan (1993) revealed that advertising can influence perceived quality. Heavy advertising and emphasizing the favorable attributes of the brand enable advertising to create quality perceptions, specifically for experience goods (Simon \& Sullivan, 1993), that is, the consumers cannot verify its quality prior to purchase (Nelson, 1974). In addition, Buil, et al. (2013) stated that advertising does not necessarily supports perceived quality, if the advertising investments reach the saturation point. Based on the hierarchy of effects model, advertising participates in creating brand loyalty, (Yoo et al., 2000). Consequently, author is directed to form the following hypothesis:

Advertising positively affects brand awareness, brand associations, perceived quality, and brand loyalty.

\subsection{Monetary Promotion and Dimensions of Brand Equity}

In case of comparing between promotion and advertising, Cobb-Walgren et al. (1995) stated that while advertising generates value, promotion generates volume. By reviewing literature, the author found different arguments, in terms of the investigating the role of sales promotions on brand equity (Joseph \& Sivakumaran, 2009). Based on the type of promotion the effect of promotion on brand equity would be predictable (Buil et al., 2013). The knowledge about the brand in consumer's memory that resulted from short-run marketing activities (e.g., price promotions) affects the success of the future marketing programs (Keller, 1993). Huang and Sarigöllü (2012) stated that, using price promotions would result in positive consequences (i.e., increasing brand exposure, and usage experience). It was referred that, using price promotions would negatively affect the long-run of brand assets (Park \& Srinivasan, 1994; Simon \& Sullivan, 1993). In addition, Bawa and Shoemaker (1987) suggest that, after the redemption purchase, the majority of consumers return to buy their precoupon choice behavior. Park and Srinivasan (1994) referred that price promotions have negative effect on brand profitability, which directs manufacturers to seek ways to support loyalty toward their brands. Although, Huang and Sarigöllü (2012) found a positive influence of price promotion on brand awareness, Valette-Florence, Guizani and Merunka (2011) and Yoo et al (2000) stated that brand equity negatively influenced by increasing sales promotions. Buil et al. (2013) and Yoo et al. (2000) revealed that monetary promotions affect perceived quality negatively. Buil et al (2013) and Yoo et al. (2000) stated that monetary promotions do not increase the strength of brand associations. Accordingly, author hypothesizes that:

Monetary promotions negatively affect perceived quality, and brand associations.

\subsection{The Interrelationships among Dimensions of Brand Equity}

Brand equity has a set of dimensions (Yoo et al., 2000). Buil et al. (2013) found that, the dimensions of brand equity inter-relate. Causal order among the dimensions of brand equity is an important matter in the context of studying brand equity (Buil et al., 2013). Keller (1993, p. 3) stated that "brand awareness affects consumer decision making by influencing the formation and strength of brand associations in the brand image." Also, 
perceptions can be influenced by brand awareness (Aaker, 1996). Brand awareness affects positively perceived quality (Buil et al., 2013) and brand associations (Buil et al., 2013; Keller, 1993). Aaker (1996) stated that, in some contexts, brand awareness considered a driver of brand loyalty. Buil et al. (2013) and Yoo et al. (2000) revealed that perceived quality enhances brand loyalty. Buil et al. (2013) stated that brand associations have a positive impact on brand loyalty. As mentioned earlier, brand associations could be seen as anything about brand that the customer's memory holds (Chattopadhyay et al., 2010). "These associations include functional qualities, benefits, purchase and consumption situations" (Romaniuk \& Nenycz-Thiel, 2013, p. 68). Building on the notion that brand associations resulted from consumer-brand contact (Buil et al., 2013) it is expected that brand associations influence the consumer perceived quality. Consequently, author is directed to form the following hypotheses:

Brand awareness positively affects perceived quality, brand associations, and brand loyalty.

Brand associations positively affect brand loyalty, and Perceived quality.

Perceived quality positively affects brand loyalty.

\section{Method}

\subsection{Measurement}

There is a remarkable concentration of brand equity studies on customer perception (Kim et al., 2008). Investigating the actual marketing efforts is not recommended, as controlling them would not be feasible (Yoo et al., 2000), and consumers have limited knowledge in terms of actual marketing efforts (Valette-florence et al., 2011). In addition, perception of consumer toward marketing actions provide strong predictors of brand evaluation (Valette-florence et al., 2011), and relates to consumer psychology than actual marketing actions (Yoo et al., 2000). Like previous research (Buil et al., 2013; Valette-florence et al., 2011; Yoo et al., 2000), the current research is dependent on the consumer's perception in terms of marketing efforts. Building on previous research, the current study measured its variables, as follows: Yoo et al. (2000), in terms of measuring the distribution intensity, adverting spending, brand loyalty, and overall brand equity variables; Yoo et al. (2000) and Buil, et al. (2013), in terms of measuring monetary promotion; Netemeyer et al. (2004) and Yoo et al. (2000) in terms of measuring brand awareness; Buil et al. (2013) in terms of measuring brand associations; and Kim and Hyun (2011) in terms of measuring perceived quality. Analysis of reliability and validity indicates adequate level of psychometric properties for all study variables.

Table 1. Reliability statistics

\begin{tabular}{lll}
\hline Variables & Number of Items & Cronbach's Alpha \\
\hline Distribution Intensity & 2 & .668 \\
Monetary Promotions & 3 & .741 \\
Advertising Spending & 3 & .784 \\
Brand Awareness & 3 & .769 \\
Brand Associations & 7 & .871 \\
Perceived Quality & 4 & .814 \\
Brand Loyalty & 3 & .867 \\
Overall Brand Equity & 3 & .810 \\
\hline
\end{tabular}

As shown in Table 1, the Cronbach's Alpha for the study dimensions ranged approximately from 7 to 8 which refers to internal consistency between the items for each variable.

Table 2. Item-total statistics

\begin{tabular}{ll}
\hline & Corrected Item-Total Correlation \\
\hline Distribution Intensity & \\
Item 1 & .308 \\
Item 2 & .308 \\
Monetary Promotions & \\
Item 3 & .491 \\
Item 4 & .451 \\
Item 5 & .413 \\
\hline
\end{tabular}




\begin{tabular}{ll}
\hline Advertising Spending & .523 \\
Item 6 & .396 \\
Item 7 & .583 \\
Item 8 & \\
Brand Awareness & .388 \\
Item 9 & .453 \\
Item 10 & .452 \\
Item 11 & \\
Brand Associations & .574 \\
Item 12 & .736 \\
Item 13 & .435 \\
Item 14 & .642 \\
Item 15 & .780 \\
Item 16 & .732 \\
Item 17 & .652 \\
Item 18 & \\
Perceived Quality & .656 \\
Item 19 & .723 \\
Item 20 & .607 \\
Item 21 & .561 \\
Item 22 & .701 \\
Brand Loyalty & .638 \\
Item 23 & \\
Item 24 & .804 \\
Item 25 & \\
Overall Brand Equity & \\
Item 26 & \\
Item 27 & \\
Item 28 & \\
\hline
\end{tabular}

Table 2 shows that the corrected item-total correlations ranged approximately from 0.3 to 0.8 which indicate that the study measurements are valid. Based on Table $1 \& 2$, author concludes that, analysis of reliability and validity indicates adequate level of psychometric properties for all study variables.

\subsection{Choosing Products and Brands}

The current researcher seeks valid and reliable responses, and to issue some generalizability. That is based two important criteria: first, selecting available and well-known product categories; second; these categories would exhibit a wide range of consumer products among consumers (i.e., Egyptians consumers) (Buil et al., 2013). Accordingly, researcher chose two different categories (i.e., cell phone and laptop). These varied categories may reflect different aspects, such as purchase frequency, and would be considered highly-involvement products. This enables a comparison between categories, that is, deemed important (Kirshnan, 1996). Based on the previous criteria, Nokia, Samsung, G-Tide, Dell, HP, Toshiba, are the brands that have been selected, in terms of such categories, respectively.

\subsection{Sample and Procedure}

Respondents were asked to complete self-administered questionnaire. Then the research survey has been done to test the hypotheses, using data obtained from under graduate students enrolled in Faculty of Commerce courses, Mansoura University, Egypt, during the fall semester, of the academic year 2013/2014. The results were built on 497 questionnaires, represented approximately $83 \%$ response rate.

\subsection{Model Fit Assessment}

Relying on Ebeid and Gadelrab (in press, p.7), model fit assessment was manipulated, as follows; "overall goodness of fit of the model to the data was assessed based on multiple criteria using both absolute and relative fit indices; Root Mean Square Error of Approximation was used with values less than 0.07 indicating acceptable fit and less than 0.05 indicating good fit; relative and noncentrality-based goodness-of-fit indices were used in evaluating model fit as well; the Comparative Fit Index, the Tucker-Lewis Index, and Incremental Fit index with values of 0.90 and greater were indicative of good fit; Standardized Root Mean-squared Residuals (SRMR) was 
used, with values of less than 0.08 indicating relatively good fit between the hypothesized model and the observed data; values greater than 0.08 might indicate an area of local misfit."

\section{Results}

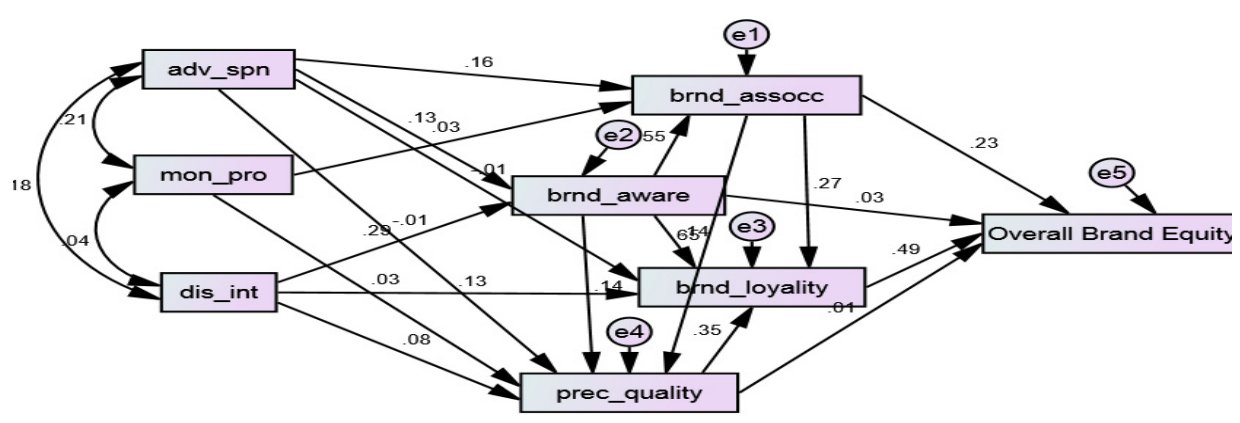

Figure 1. Model's parameter estimates

Table 3. Model fit summary

\begin{tabular}{llll}
\hline Fit Index & Value & Fit Index & Value \\
\hline Chi squre & 12.271 & TLI & 0.980 \\
& $(\mathrm{p}=.056)$ & & \\
Chi squre / df & 2.045 & CFI & 0.996 \\
IFI & 0.996 & RMSEA & 0.046 \\
\hline
\end{tabular}

According chi square, their is no significant differences between the proposed model and the collected data. The value of Chi square/ degree of freedom (df) equals 2.045 suggests excellent model data fit. With regard to baseline comparison, values of IFI TLI CFI were at the optimum value of perfect fit $(.996, .980, .996)$. RMSEA value was .046 indicates almost no difference between the model and data. Therefore, the proposed model reflects perfect fit to the data.

Table 4. Standardized regression weights

\begin{tabular}{lllll}
\hline & & & Estimate & P \\
\hline brnd_awa & $<---$ & adv_spn & 0.131 & 0.002 \\
brnd_awa & $<---$ & dis_int & 0.292 & $<0.001$ \\
brnd_asso & $<---$ & adv_spn & 0.159 & $<0.001$ \\
brnd_asso & $<---$ & mon_pro & 0.033 & 0.369 \\
brnd_asso & $<---$ & brnd_awa & 0.545 & $<0.001$ \\
prec_quali & $<---$ & adv_spn & -0.011 & 0.709 \\
prec_quali & $<---$ & mon_pro & 0.030 & 0.314 \\
prec_quali & $<---$ & dis_int & 0.082 & 0.007 \\
prec_quali & $<---$ & brnd_awa & 0.142 & $<0.001$ \\
prec_quali & $<---$ & brnd_asso & 0.652 & $<0.001$ \\
brnd_loyal & $<---$ & adv_spn & -0.015 & 0.656 \\
brnd_loyal & $<---$ & dis_int & 0.128 & $<0.001$ \\
brnd_loyal & $<---$ & brnd_asso & 0.268 & $<0.001$ \\
brnd_loyal & $<---$ & brnd_awa & 0.137 & $<0.001$ \\
brnd_loyal & $<---$ & prec_quali & 0.351 & $<0.001$ \\
Ovbra eq & $<---$ & brnd_awa & 0.034 & 0.406 \\
ov_bra eq & $<---$ & brnd_loyal & 0.494 & $<0.001$ \\
ov_bra eq & $<---$ & prec_quali & 0.010 & 0.843 \\
ov_bra eq & $<---$ & brnd_asso & 0.235 & $<0.001$ \\
\hline
\end{tabular}


As shown in Table 4, the majority of regression weights were significant at .001 level, except one that was at .007 level, and two regression weights that were significant at .05 level. Table 4 results in the following main significant and positive influences: advertising spend influences brand awareness, and brand associations; distribution intensity influences brand awareness, brand loyalty, and perceived quality; brand awareness influences brand associations, perceived quality, and brand loyalty; brand associations influence perceived quality, brand loyalty; perceived quality influences brand loyalty.

Table 5. Correlations

\begin{tabular}{lllll}
\hline & & & Estimate & P \\
\hline adv_spn & $<-->$ & mon_pro & .210 & $<0.001$ \\
adv_spn & $<-->$ & dis_int & .180 & $<0.001$ \\
mon_pro & $<-->$ & dis_int & .045 & .318 \\
\hline
\end{tabular}

As shown in Table 5, the weights regarding the correlations between adverting spend and monetary promotion, and between adverting spend and distribution intensity were significant at .001 level, while the weight in terms of the correlation between monetary promotion and distribution intensity was insignificant (.318).

Table 6. Variances

\begin{tabular}{lll}
\hline & Estimate & $\mathrm{P}$ \\
\hline adv_spn & .895 & $<0.001$ \\
mon_pro & .596 & $<0.001$ \\
dis_int & .660 & $<0.001$ \\
e2 & .669 & $<0.001$ \\
e4 & .338 & $<0.001$ \\
e1 & .444 & $<0.001$ \\
e3 & .685 & $<0.001$ \\
e5 & .577 & $<0.001$ \\
\hline
\end{tabular}

As shown in Table 6, all variances were significant at .001 level.

\section{Discussion and Implications}

The current research aims at investigating the potential effects of distribution intensity, advertising, and monetary promotion (i.e., brand equity drivers) on brand equity dimensions, that is, brand awareness, brand associations, brand loyalty, and perceived quality. In addition, the research investigates the inter-relationships among the dimensions of brand equity. The research has a set of implications. Advertising considered an effective marketing communication tool that used to enhance the brand awareness and brand associations, that reveals the advertising role in creating brand equity. Remarkable positive influence of distribution intensity on brand awareness, brand loyalty, and perceived quality would get the attention of manufacturers to cover the market by increasing the availability level of their brands within a large number of stores, unlike the notion that refers to exclusively distributing brands in terms of getting the retailers' support (Yoo et al., 2000). Regarding the interrelations among brand equity dimensions, brand awareness positively influences brand associations, perceived quality, and brand loyalty. Matching with previous research (Buil et al., 2013), current research argues that brand awareness is the starting point to constitute the customer-based brand equity. Current study reveals that brand associations influence perceived quality, brand loyalty. In turn, perceived quality positively influence brand loyalty, unlike Buil et al.'s (2013) finding. This would refer to brand association as a pivotal dimension in constituting a successful brand. At this point, researcher argues that investing in advertising would be appropriate to enhance brand awareness and brand associations as well, parallel with increasing the number of stores that deal with the brand, in terms of supporting brand awareness. In addition, author suggests that increasing perceived quality may guarantee brand loyalty. Eventually, brand managers and retailers share the task of constituting the consumer impressions (Buchanan, Simmons, \& Bickart, 1999), thus author argues that both of them should be interested in continuously investigating the equity of brands in concern, as it provides them with a feedback about how far they successfully manage their brand marketing mix. In the same vein, this would result in issuing joint advertising campaigns to enhance the brand equity. 


\section{Limitation and Further Research}

The current research has several limitations, as with any research. The current research relies on the perceptual measures that resulted in specific finding, which may vary more (less) the finding resulted from another research that uses actual measures. The current research uses two product categories, for more generalizability, it is recommended to use different categories, in different cultures. Despite the previous limitation, the current research participate in providing more insight into rationalizing marketing decisions, by determining predictable effects of marketing elements on brand equity. As many developing countries are relying on importing to fulfill their needs, author suggests investigating the role of product-country-image in creating the customer-basedbrand equity in such countries.

\section{References}

Aaker, D. A. (1996). Measuring brand equity across products and markets. California Management Review, 38, 102-120. http://dx.doi.org/10.2307/41165845

Ailawadi, K. L., Lehmann, D. R., \& Neslin, S. A. (2003). Revenue Premium as an Outcome Measure of Brand Equity. Journal of Marketing, 67(4), 1-17. http://dx.doi.org/10.1509/jmkg.67.4.1.18688

Baldauf, A., Cravens, K. S., Diamantopoulos, A., \& Zeugner-Roth, K. P. (2009). The impact of product-country image and marketing efforts on retailer-perceived brand equity: an empiricalanalysis. Journal of Retailing, 85, 437-452. http://dx.doi.org/10.1016/j.jretai.2009.04.004

Bambauer-Sachse, S., \& Mangold, S. (2011). Brand equity dilution through negative online word-of-mouth communication. Journal of Retailing and Consumer Services, 18, 38-45. http://dx.doi.org/10.1016/j.jretconser.2010.09.003

Bawa, K., \& Shoemaker, R. W. (1987). The Effects of a Direct Mail Coupon on Brand Choice Behavior. Journal of Marketing Research, 24, 370-376. http://dx.doi.org/10.2307/3151384

Bello, D. C., \& Holbrook, M. B. (1995). Does an absence of brand equity generalize across product classes? Journal of Business Research, 34, 125-131. http://dx.doi.org/10.1016/0148-2963(95)00008-G

Berry, L. L. (2000). Cultivating service brand equity. Journal of Academy of Marketing Science, 28(1), 128-137. http://dx.doi.org/10.1177/0092070300281012

Buchanan, L., Simmons, C. J., \& Bickart, A. B. (1999). Brand Equity Dilution: Retailer Display and Context Brand Effects. Journal of Marketing Research, 36(3), 345-355. http://dx.doi.org/10.2307/3152081

Buil, I., \& De Chernatony, L., \& Martinez, E. (2013). Examining the role of advertising and sales promotions in brand equity creation. Journal of Business Research, 66, 115-122. http://dx.doi.org/10.1016/j.jbusres.2011.07.030

Chattopadhyay, T., Dutta, R. N., \& Sivani, S. (2010). Media mix elements affecting brand equity: A study of the Indian passenger car market. Management Review, 22, 173-185.

Cobb-Walgren, C. J., Ruble, C. A., \& Donthu, N. (1995). Brand Equity, Brand Preference, and Purchase Intent. Journal of Advertising, 24(3), 25-40. http://dx.doi.org/10.1080/00913367.1995.10673481

DelVecchio, D., Jarvis, C. B., Klink, R. R., \& Dineen, B. R. (2007). Leveraging Brand Equity to Attract Human Capital. Marketing Letters, 18, 149-164. http://dx.doi.org/10.1007/s11002-007-9012-3

Dodds, W. B., Monroe, K. B., \& Grewal, D. (1991). Effects of Price, Brand, and Store Information on Buyers' Product Evaluations. Journal of Marketing Research, 28, 307-319. http://dx.doi.org/10.2307/3172866

Ebeid, Y. A., \& Gadelrab, F. H. (2014). Investigating the role of negative word-of-mouth communication in increasing the customer-brand equity dilution.

Erdem, T., \& Swait, J. (1998). Brand Equity as a Signaling Phenomenon. Journal of Consumer Psychology, 7 , 131-157. http://dx.doi.org/10.1207/s15327663jcp0702_02

Erdem, T., Swait, J, Broniarczyk, S., Chakravarti, D., Kapferer, J. N., Keane, M., ... Zettelmeyer, F. (1999). Brand Equity, Consumer Learning and Choice. Marketing Letters, 10, 301-318. http://dx.doi.org/10.1023/A:1008135224357

Hoyer, W. D., \& Brown, S. P. (1990). Effects of Brand Awareness on Choice for a Common, Repeat-Purchase Product. Journal of Consumer Research, 17, 141-148. http://dx.doi.org/10.1086/208544

Huang, R., \& Sarigöllü, E. (2012). How brand awareness relates to market outcome, brand equity, and the marketing mix. Journal of Business Research, 65, 92-99. http://dx.doi.org/10.1016/j.jbusres.2011.02.003 
Joseph, J., \& Sivakumaran, B. (2009). The Moderating Effect of Loyalty on the Relationship of Sales Promotions and Brand Equity. Advances in Consumer Research, 7, 263-264.

Keller, K. L. (1993). Conceptualization, measuring and managing customer-based brand equity. Journal of Marketing, 57, 1-22. http://dx.doi.org/10.2307/1252054

Keller, K. L., \& Lehmann, D. R. (2006). Brands and branding: research findings and future priorities. Marketing Science, 25(6), 740-759. http://dx.doi.org/10.1287/mksc.1050.0153

Kim, J. H., \& Hyun, Y. J. (2011). A model to investigate the influence of marketing-mix efforts and corporate image on brand equity in the IT software sector. Industrial Marketing Management, 40, 424-438. http://dx.doi.org/10.1016/j.indmarman.2010.06.024

Kim, W. G., Jin-Sun, B., \& Kim, H. J. (2008). Multidimensional customer-based brand equity and its consequences in midpriced hotels. Journal of Hospitality \& Tourism Research, 32, 235-254. http://dx.doi.org/10.1177/1096348007313265

Kirshnan, H. S. (1996). Characteristics of memory associations: a consumer-based brand equity perspective. International Journal of Research in Marketing, 13, 389-405. http://dx.doi.org/10.1016/S0167-8116(96)00021-3

Kotler, P., \& Armstrong, G. (2008). Principles of Marketing (12th ed.). New Jersey: Pearson Prentice Hall.

Nelson, P. (1974). Advertising as information. The Journal of Political Economy, 82, 792-754. http://dx.doi.org/10.1086/260231

Netemeyer, R. G., Krishnan, B., Pullig, C., Wang, G. P., Yagci, M., Dean, D., ... Wirth, F. (2004). Developing and validating measures of facets of customer-based brand equity. Journal of Business Research, 57, 209-224. http://dx.doi.org/10.1016/S0148-2963(01)00303-4

Parameswaran, R., \& Yaprak, A. (1987). A Cross-National Comparison of Consumer Research Measures. Journal of International Business Studies, 18, 35-49. http://dx.doi.org/10.1057/palgrave.jibs.8490398

Park, C. S., \& Srinivasan, V. (1994). A Survey-Based Method for Measuring and Understanding Brand Equity and Its Extendibility. Journal of Marketing Research, 31, 271-288. http://dx.doi.org/10.2307/3152199

Romaniuk, J., \& Nenycz-Thiel, M. (2013). Behavioral brand loyalty and consumer brand associations. Journal of Business Research, 66, 67-72. http://dx.doi.org/10.1016/j.jbusres.2011.07.024

Simon, C. J., \& Sullivan, M. W. (1993). The Measurement and Determinants of Brand Equity: A Financial Approach. Marketing Science, 12, 28-52. http://dx.doi.org/10.1287/mksc.12.1.28

Soberman, D. A. (2009). Marketing agencies, media experts and sales agents: Helping competitive firms improve the effectiveness of marketing. Internatioanl Journal of Research in Marketing, 26, 21-33. http://dx.doi.org/10.1016/j.jiresmar.2008.05.003

Srinivasan, V., Park, C. S., \& Chang, D. R. (2005). An approach to the measurement, analysis, and prediction of brand equity and its sources. Management Science, 9, 1433-1448. http://dx.doi.org/10.1287/mnsc. 1050.0405

Valette-Florence, P., Guizani, H., \& Merunka, D. (2011). The impact of brand personality and sales promotions on brand equity. Journal of Business Research, 64, 24-28. http://dx.doi.org/10.1016/j.jbusres.2009.09.015

Van Riel, A. C. R., Mortanges, C. P., \& Streukens, S. (2005). Marketing antecedents of industrial brand equity: An empirical investigation in specialty chemicals. Industrial Marketing Management, 34, 841-847. http://dx.doi.org/10.1016/j.indmarman.2005.01.006

Yoo, B., \& Donthu, N. (2001). Developing and validating multidimensional consumer-based brand equity scale. Journal of Business Research, 52, 1-14. http://dx.doi.org/10.1016/S0148-2963(99)00098-3

Yoo, B., Donthu, N., \& Lee, S. (2000). An examination of selected marketing mix elements and brand equity. Journal of the Academy of Marketing Science, 28, 195-211. http://dx.doi.org/10.1177/0092070300282002

\section{Copyrights}

Copyright for this article is retained by the author(s), with first publication rights granted to the journal.

This is an open-access article distributed under the terms and conditions of the Creative Commons Attribution license (http://creativecommons.org/licenses/by/3.0/). 